\title{
Proceeding
}

\section{Employment time-out in volleyball formative stages}

\author{
CARMEN FERNÁNDEZ-ECHEVERRIA 14 , ALEXANDER GIL1', LUÍS GARCÍA-GONZÁLEZ², FILIPE \\ CARRASCO SOARES ${ }^{1}$, FERNANDO CLAVER ${ }^{1}$, FERNANDO DEL VILLAR ${ }^{1}$. \\ ${ }^{1}$ Department of Didactics of the Musical, Plastic and Corporal Expression. Faculty of Sport Sciences. University of \\ Extremadura, Spain \\ ${ }^{2}$ Department of Didactics of the Musical, Plastic and Corporal Expression. Faculty of Health and Sport Sciences. \\ University of Zaragoza, Spain
}

\begin{abstract}
Fernández-Echeverria C, Gil A, García-González L, Carrasco F, Claver F, Del Villar, F. Employment timeout in volleyball formative stages. J. Hum. Sport Exerc. Vol. 8, No. Proc3, pp. S591-S600, 2013. The main objective of the research was to analyze the characteristics of the time-outs requested in the Spanish Championship of Regional Selections in 2010 (Under-14 and Under-16, male and female categories). To this end, 232 timeouts were analyzed, a game of each of the teams participating in the championship was collected. The variables considered in the study were: number of consecutive serves of the opposing team that run until the time-out was ordered, number of serves that are made until the team requesting the timeout gets the serve, points of difference between the teams at the moment the time-out was ordered and moment of the set in what the time-out was ordered. The results showed that: more than $64 \%$ of cases, the team orders the time-out when the opposing team pass two serves or less; in $75 \%$ of cases, the team that orders the time-out gets the serve when the opposing team spends two serves or less; $37 \%$ of time-outs were ordered with a difference of 2,3 or 4 points, and $40 \%$ with a difference of 5 points or more. In addition, time-outs were distributed balanced in the different moments of the set, moment 1 or initial part of the set $(34.5 \%)$, moment 2 or intermediate part of the set $(34.1 \%)$ and moment 3 or final part of the set (31.5\%). Key words: TIMES OF REST, CRITICAL MOMENTS, TEAM SPORTS, FORMATIVE CATEGORIES.
\end{abstract}

Corresponding author. Facultad de Ciencias del Deporte. Universidad de Extremadura. Av. Universidad, s/n. 10071 Cáceres (España).

E-mail: cafernandeze@unex.es

Performance Analysis Workshop, 2 - 5 April 2013, Alicante, Spain

JOURNAL OF HUMAN SPORT \& EXERCISE ISSN 1988-5202

(c) Faculty of Education. University of Alicante

doi:10.4100/jhse.2013.8.Proc3.04 


\section{INTRODUCTION}

The figure of the coach in the sports context is highly relevant because through their words and actions they influence both in athletes' performance and in their social and emotional welfare (Cushion \& Jones, 2001). The intervention of the coach for team management is one of the numerous variables that influence athletes both in training and competition (Moreno et al., 2004).

During a competition, the various interruptions in play are one of the main tools available to coaches to intervene on the game and directly affect on the most relevant aspects of the game (Ortega et al., 2007; Rodrigues, 2002; Sampaio et al., 2006; Sánchez et al, 2006).

In volleyball, one of the pauses or interruptions that the coach can use are called time-outs. According to the rules of volleyball (REFVB, 2013: 15.4), team managers have two timeouts per set played, with a duration of 30 seconds each.

Timeout can be used by coaches, for both psychological or tactical reasons (Bergeles, 1993; Zetou \& Haritonidis, 2002) and his intention is to influence the pace of the game, allowing the occurrence of a game pause and the opportunity for the coach to communicate specific instructions that may influence specific actions to be executed later and that may influence athletic performance (Moreno et al., 2005).

Time-outs should be managed properly considering its availability, requesting them for a specific purpose (Miller, 2005) and transmitting clear, concise and accurate information (Estrada \& Pérez, 2008; González, 2007; Moreno et al., 2005).

Some authors have been concerned to identify some reasons why you may request a timeout, of which we highlight: to lose three or more consecutive points, when the team was confused and disorganized, when the team does not develop the tactical and strategic plan provided, when trying to change the pace of the game and adapt to our expectations, to calm down the players in cases of conflicts between them or to encourage the players (Herrera et al., 1996; Thinnes, 1992; Zhang, 1993).

Also, to be clear why you are requesting a time-out, the coach should think what is the best time to order it, taking into account aspects such as the game flow, how are his/her players, if the coach will give all the information or his players will contribute to the conversation (Hebert, 1991). Other aspects that should be considered are the scoreboard and the moment of the set (Zetou et al., 2008).

In relation to time-outs, qualitative research have been developed, using content analysis, focused primarily in knowing the information that coaches provide to his players in different sports. In basketball, was analyzed the evolution of verbal behavior of the coaches and the amount of information provided in accordance with the situation in the scoreboard, concluding that the verbal behavior of coaches varies during the matches. (Lorenzo et al., 2006; Montero et al., 2005).

In volleyball, some studies focused on analyzing the type of information transmitted by the coaches at high level (Cloes et al., 1993) and other levels (Pina \& Rodrigues, 1997) indicate that during time-outs, tactical information prevail over psychological, especially at high level. While, at lower levels, coaches more often use technical and psychological information. 
In volleyball, Garcia-Tormo et al. (2003) analyzed 144 time-outs in order to know what situations cause timeout ordering and it effectiveness. It was achieved by coaches who participated in the Spanish Championship Under-18 in 2003. Their results indicated that the frequency in which coaches ordered the time-out was increased at the end of the set, and a high efficiency and good performance thereof.

On the other hand, we highlight studies that deal with the issue of timeout from both qualitative and quantitative methods as in the study with a in high-level volleyball sample of Zetou et al. (2008), whose objective was to analyze the management of time-outs required in relation to the scoreboard and analyze the comments made by coaches during such time-outs. Their results indicated that coaches use time-outs, especially when they were losing and that this information was primarily tactical (50.85\%).

The main objective of the research was to analyze the use of timeouts by the coaches of the teams participating in the Spanish Championship of Regional Selections in 2010 (Under-14 and Under-16, male and female categories). From this general objective the following specific objectives were raised: ordered.

o To know the number of consecutive serves the opposing team made until the time-out was

0 To know the number of serves that are made until the team requesting the time-out gets the serve.

0 To know the points of difference between the teams at the moment the time-out was ordered.

0 To know the moment of the set in what the time-out was ordered.

\section{MATERIAL AND METHODS}

\section{Participants}

The study sample was comprised of 232 time-out, corresponding to the observation of 66 female and male teams participating in the Spanish Regional Selections Championship in its Under-16 and Under-14 categories.

The serves analysed correspond to the observation of a match played by each team. This represents the observation of a total of 123 sets, of which 59 sets belonged to the Under-14 category and 67 sets belonged to the Under-16 category.

The protocol was fully approved by the Research Ethics Committee of the University of Extremadura (Spain). All players and their parents or guardians were fully informed about the study, and they signed a consent form.

\section{Measures}

The variables considered in the study were: number of serves made by the opposing team until the timeout was ordered, number of serves that are made until the team requesting the time-out gets the serve, points of difference between the teams at the moment the time-out was ordered and moment of the set in what the time-out was ordered.

Number of serves made by the opposing team until the time-out was ordered. The following options were differentiated.

- 2 serves or less.

- 3 serves.

- 4 serves or more. 
Number of serves that are made until the team requesting the time-out gets the serve. The following options were differentiated:

- 2 serves or less.

- 3 serves.

- 4 serves or more.

Points of difference between the teams at the moment the time-out was ordered. The following options were differentiated:

- Difference of 1 point or less.

- Difference of 2, 3 or 4 points.

- Difference of 5 points or more.

Moment of the set in what the time-out was ordered. The following options were differentiated:

- Initial moment (0-8 points).

- Half moment (9-16 points).

- Final moment (17-25 or more points).

\section{Procedures}

The matches were recorded using a SONY HDR-XR155 digital camera on M2TS format. This camera was located at one of the ends of the court, guaranteeing a height of $5 \mathrm{~m}$ above floor level, to obtain an optimal line of sight.

After collecting the data, all the matches were observed by one single observer. To guarantee the reliability of the observation, one observer, with experience in this function and with good knowledge of volleyball, carried out a training process using, in the different training sessions, samples with different characteristics (category, gender, position in the classification), and exceeding $10 \%$ of the total sample, indicated by Tabachnick \& Fidell (2007). The intraobserver Cohen's Kappa values reached, in the observation of all the variables, were higher than .81 , which was the minimum value considered to be almost perfect agreement (Landis \& Koch, 1977). To guarantee the time reliability of the measurement, the same coding was developed on two occasions, with a time difference of 10 days, obtaining Cohen's Kappa values of over .81 .

Statistical analysis of data was performed using SPSS 19.0.

\section{RESULTS}

Then, we present a descriptive analysis of each of the variables considered in the study:

Number of serves made by the opposing team until the time-out was ordered.

Table 1 shows that over $64 \%$ of the time-outs they were ordered within 2 serves or less the opposite. 
Table 1. Serves the opposite frequency that elapse until the timeout was ordered.

\begin{tabular}{lllll} 
& Frequency & Percentage & $\begin{array}{l}\text { Percentage } \\
\text { valid }\end{array}$ & $\begin{array}{l}\text { Percentage } \\
\text { cumulative }\end{array}$ \\
\hline 2 serves or less & 150 & 64.7 & 64.7 & 64.7 \\
3 serves & 35 & 15.1 & 15.1 & 79.7 \\
4 serves or more & 47 & 20.3 & 20.3 & 100.0 \\
Total & 232 & 100.0 & 100.0 & \\
\hline
\end{tabular}

Number of serves that are made until the team requesting the time-out gets the serve.

Table 2 shows that over $75 \%$ of time-outs were ordered must spend 2 serves or less for the team that recovers the serve ordered.

Table 2. frequency of serves that are made until the team requesting the time-out gets the serve.

\begin{tabular}{lllll} 
& Frequency & Percentage & $\begin{array}{l}\text { Percentage } \\
\text { valid }\end{array}$ & $\begin{array}{l}\text { Percentage } \\
\text { cumulative }\end{array}$ \\
\hline 2 serves or less & 176 & 75.9 & 75.9 & 75.9 \\
3 serves & 29 & 12.5 & 12.5 & 88.4 \\
4 serves or more & 27 & 11.6 & 11.6 & 100.0 \\
Total & 232 & 100.0 & 100.0 & \\
\hline
\end{tabular}

Points of difference between the teams at the moment the Time-Out was ordered.

Table 3 shows that $37 \%$ and $40 \%$ of time-outs were requested with a difference of 2,3 or 4 points, 5 points or more respectively. However, $22 \%$ of time-out were ordered of 1-point difference or less.

Table 3. Frequency points of difference between the teams at the moment the Time-Out was ordered.

\begin{tabular}{lllll} 
& Frequency & Percentage & $\begin{array}{l}\text { Percentage } \\
\text { valid }\end{array}$ & $\begin{array}{l}\text { Percentage } \\
\text { cumulative }\end{array}$ \\
\hline Difference of 1 point or less & 52 & 22.4 & 22.4 & 22.4 \\
Difference of 2, 3 or 4 points & 87 & 37.5 & 37.5 & 59.9 \\
Difference of 5 points or more & 93 & 40.1 & 40.1 & 100.0 \\
Total & 232 & 100.0 & 100.0 & \\
\hline
\end{tabular}

Moment of the set in what the time-out was ordered. 
Table 4 shows that $34.5 \%$ of time-outs were ordered at moment 1 (0-8 points), $34.1 \%$ of time were ordered at moment 2 (9-16 points) and $31.5 \%$ of the time-outs were ordered at time 3 (17-25 points).

Table 4. Frequency of moment of the set in what the time-outs were ordered.

\begin{tabular}{lllll} 
& & & Percentage & $\begin{array}{l}\text { Percentage } \\
\text { cumulative }\end{array}$ \\
\hline Moment 1 (0-8 puntos) & Frequency & Percentage & valid & cumb \\
Moment 2 (9-16 puntos) & 80 & 34.5 & 34.5 & 34.5 \\
Moment 3 (17-25 o más puntos) & 79 & 34.1 & 34.1 & 68.5 \\
Total & 232 & 31.5 & 31.5 & 100.0 \\
\hline
\end{tabular}

\section{DISCUSSION AND CONCLUSIONS}

The main objective of the research was to analyze the characteristics of the timeouts requested in the Spanish Championship of Regional Selections in 2010 (Under-14 and Under-16, male and female categories).

Regarding the first objective, number of serves made by the opposing team until the time-out was ordered. The results showed that over $64 \%$ of the time-outs they were ordered within 2 serves or less made by the opposite. The percentage of time-outs the game orders at 3 and 4 serves or more of the contrast is lower with percentages of $15 \%$ and $20 \%$, respectively.

Our results agree with those obtained by Gil et al. (2010), who analyzed 87 time-outs in the Spanish Championship of Regional Selections in 2005 (Under-16 category). Their results indicate that over $64 \%$ of cases, teams wait between 1 and 2 serves made by the contrary to order a time-out, being very few such timeouts ordered after 5 and 6 serves the opposite.

Garcia-Tormo et al. (2003), in another U-18, with a sample of 144 time-outs ordered by coaches participating in the Spanish Championship Under-18 in 2003. In line with our results, they found that the time-outs were ordered when the other team was getting between 1 and 3 points in a row, being very small percentage of time-outs ordered after 5 or 6 serves. These results show that the formative stages coaches, as in high level (Zetou et al., 2008), will help in time-outs during times of disadvantage, in order that the opposing team does not move away on the score. Today we see that the proposal of Diaz (1997) to ask time-outs when you lose three or more consecutive points, was not followed rigorously. This can happen because in those moments (Diaz's proposal) the scoring system was different to present.

In other sports, in line with our results, application timeout occurs at unfavourable moments. In basketball, Ortega et al. (2010) indicated that the main game situation that triggers a time-out order is not scoring at more than three of the five previous phases of attack to the order. In another study in handball, Valle et al. (2012), concluded that teams ordering more time-outs are those who have made a prrevious negative partial and that $93 \%$ of the teams order this time-out, after receiving a goal from the opposite (negative action for the team that orders the time-out). 
Regarding the second objective, which was intended to know the number of serves that are made until the team requesting the time-out gets the serve. The results showed that over $75 \%$ of time-outs were ordered must spend 2 serves or less for the team that recovers the serve ordered. However, very few cases where they should spend 3 and 4 serves or more serves to recover.

In line with our results, Gil et al. (2010), analyzed time-outs in Under-14 indicated that $78 \%$ of the ordered time-out to recover the serve, two serve or earlier.

In addition, Garcia-Tormo et al. (2003) in their study at Under-18, indicated that $78 \%$ of the times that a time-out is ordered, the team that ordered it, recovers the serve in the next two plays, breaking the losing streak.

In other sports like basketball, it cannot be counted the number of serves you need to cut the pace of play and recover the possession of the ball. But in the study of Ortega et al. (2010) that recorded a total of 80 time-outs for 14 matches in the Spain Championship Men's Under-20 in basketball, the concluded that the teams request the time-outs to improve their results after the restart of the game. These results are similar to our study, because after the request of a time-out got prevent the opposing teams to dominate the game. These results highlighted the effect caused by the time-out in later actions, as having a stop in play may produce changes in tactics or variations in the behavior of the players. At formative stages does not exist a clear stability in movement patterns, more specifically in volleyball, on serving action (García Tormo et al., 2003; Gil et al., 2010).

Regarding the third objective, which tries to know the points of difference between the teams at the moment the time-out was ordered. The results showed that $37 \%$ and $40 \%$ of time-outs were requested with a difference of 2, 3 or 4 points, 5 points or more respectively. However, $22 \%$ of time-outs were ordered of 1 point difference or less.

In this line, studies in volleyball, as the one of Zetou et al. (2008), analyzed 238 time-outs in high-level, indicating that $33 \%$ of the times that were requested with a difference of 2 points to the opposing team. Our results indicate a greater difference on the score at the time of application of the time-out.

However, it is necessary to highlight that the application of the timeout without taking into account the difference in the score, seems to be associated with seeking to alter the course of the game, as indicated Rodrigues (2000) in a basketball study that analyzed ten matches made in 1997/1998, 1998/1999, and 1999/2000, seasons in different types of European competitions.

Therefore, we can say that the score is one of the variables to consider in the application of time-outs as it is a guiding element of the strategic behavior of the teams (Castilian \& White, 2004).

Regarding the fourth objective, which was intended to know the moment of the set in what the time-out was ordered. The results showed that $34.5 \%$ of time-outs were ordered at moment 1 ( $0-8$ points), $34.1 \%$ of time were ordered at moment 2 (9-16 points) and $31.5 \%$ of the time-outs were ordered at time 3 (17-25 points). Therefore time-outs orders during different times of the set are made fairly.

Studies in different sports, like basketball or water polo, take into account the various moments of the match, highlighting the crucial moments as called critical moments, defined as the initial moments, where 
you should start off well a match (Argudo, 2010; Iturriaga, 2010) and distance the score (Sampaio, 2001), the final moments (Kaminsky, 1990) or both, the initial and final moments (Newell \& Knight, 1986).

In volleyball, Zetou et al. (2008) in their study, indicate that most of the coaches preferred to order a timeout after the first technical time-out (9-16 points (36\%)) and especially after the second (17 to 21 points $39.3 \%)$.

In other sports such as the handball, Valle et al. (2012) indicates that more than the requested time-outs during the first part of the game, both the winner (66.6\%) and loser (55.5\%) teams. While, in basketball, the results of Kozar et al. (1993) \& Rodrigues (2000) showed that time-outs were ordered in the final moments of the match.

Our results indicate that the time-outs ordered during Spanish Championship of Regional Selections in 2010 were applied equally throughout the set, suggesting that in formatives stages, coaches do not have clearly identified the critical moments of the game to orders such time-outs or that these critical moments can happen throughout the set.

Finally, our results indicate that coaches order the time-outs basically when the opposite team made two or less consecutive serves, after the application of the time-out the serve is usually recovered after 2 or less serves of the opposing team, usually expect at least that the scoreboard shows a difference of 2.3 or 4 points to order the time-out and these times-outs are typically used throughout the set. These results indicate that the time-outs in formative stages are a legal resource used in team management widely used and valued by team managers and coaches during the competition.

\section{REFERENCES}

1. ARGUDO FM, ARIAS JL, RUIZ E. Influence to take the first ball on the partial and final score during the 2006 male Water Polo European Championship. Kronos. Rendimiento en el Deporte. 2009; 7(14):131-138.

2. BERGELES N. Coaching Volleyball. Athens. 1993.

3. CASTELLANO PAULIS J, BLANCO VILLASEÑOR Á. El marcador como elemento orientador del comportamiento estratégico de los equipos de fútbol: estimación y análisis de la variabilidad. Metodología de las Ciencias del Comportamiento. 2004; Vol. Especial:147-152.

4. CLOES M, DELHAES JP, PIÉRON M. Analyse des comportements d'entraineurs de volleyball pedant des rencontres officielles. Sport. 1993; 141:1625.

5. CUSHION CJ, JONES RL. A systematic observation of professional top-level youth soccer coaches. Journal of Sport Behavior. 2001; 24:354-376.

6. DÍAZ P. Voleibol. La dirección de equipo. Métodos estadísticos y evaluación competitiva. Sevilla: Wanceulen. 1997.

7. DUKE A, CORLETT J. Factors affecting university women's basketball coaches' timeout decisión. Canadian Journal of Sport Sciences. 1992; 17(4):333-337.

8. ESTRADA O, PÉREZ E. Palabras e imágenes positivas en la respuesta de ansiedad en deportistas de competición. Cuadernos de Psicología del Deporte. 2008; 8(1):31-45.

9. GARCÍA-TORMO JV, VALLADARES JA, MORANTE JC. Análisis de la eficacia de los tiempos muertos solicitados durante el Campeonato de España Juvenil Femenino 2003. Comunicación presentada en el III Congreso Internacional de entrenadores en Voleibol. Valladolid. 2003. 
10. GIL A, MORENO MP, MORENO A, GARCÍA-GONZÁLEZ L, DEL VILLAR F. Análisis de los tiempos muertos en competición de voleibol en categorías de formación. Comunicación presentada en el II Congreso Internacional de Ciencias del Deporte y Educación Física. Pontevedra. 2010.

11. GONZÁLEZ J. Herramientas aplicadas al desarrollo de la concentración en el alto rendimiento deportivo. Cuadernos de Psicología del Deporte. 2007; 7(1):61-70.

12. HEBERT M. Insights and Strategies for Winning Volleyball. USA: Human Kinetics. 1991.

13. HERRERA G, RAMOS JL, MIRELLA J. Voleibol: manual de consulta operativa para el entrenador. Bilbao: Federación Vasca de Voleibol. 1996.

14. ITURRIAGA FMA. Influence of the first possession on the partial and final score in the 2003 Water polo World Championship. Retos. Nuevas tendencias en Educación Física, Deporte y Recreación. 2010; (17):86-89.

15. KAMINSKY J. Critical game time periods in relation to teams success in college Basketball. Unpublished Master Thesis. Kent State University.1990.

16. KOZAR B, WHITFIELD KE, LORD RH, MECHIKOFF RA. Timeouts before freethrows: do the statistics support the strategy?. Perceptual and Motor Skill. 1993; 76:47-50.

17. LANDIS J, KOCH G. The measurement of observer agreement for categorial data. Biometrics. 1977; (33):159-174.

18. LORENZO J, JIMÉNEZ S, LORENZO A. Análisis del discurso del entrenador estudio de un caso aplicado al baloncesto. Kronos. Rendimiento en el deporte. 2006; 4:1-9.

19. MILLER B. The Volleyball Handbook. Winning essentials for players and coaches. Champaign, USA: Human Kinetics. 2005.

20. MONTERO A, EZQUERRO M, BUCETA JM. Variaciones de las conductas de los entrenadores infantiles a lo largo de la competición. Kronos, Rendimiento en el deporte. 2005; 4:52-56.

21. MORENO MP, CERVELLÓ E, MORENO A, RAMOS LA. Influencia del rendimiento en competición sobre la conducta verbal del entrenador de voleibol. Un estudio en etapas de iniciación. Revista de Entrenamiento Deportivo. 2004; 18(3):13-19.

22. MORENO MP, SANTOS JA, DEL VILLAR F. La comunicación del entrenador de voleibol durante la dirección de equipo en la competición. Madrid: Real Federación Española de Voleibol. 2005.

23. NEWELL P, KNIGHT B. Basketball according to Knight and Newell. Seymour: Graaessle-Mercer. 1986.

24. ORTEGA E, MARTÍNEZ JL, MARTÍNEZ G. Dirección de equipo en categorías de formación: intervención en la competición. In: Torres C. (Ed.). La formación del educador deportivo en baloncesto -Bloque Específico Nivel I-. Sevilla: Wanceulen. 2007. Pp. 129-148.

25. ORTEGA E, PALAO JM, GÓMEZ MA, IBÁÑEZ SJ, LORENZO A, SAMPAIO J. Efecto de la solicitud de tiempos muertos sobre el marcador y el tipo de defensa empleados por los equipos en baloncesto. Motricidad. European Journal of Human Movement. 2010; 24:95-106.

26. PINA R, RODRIGUES J. Análise do comportamento do treinador em competiçao. Estudo dos episódios de informaçao em voleibol. In Pedagogia do Desporto. Estudos 5. Lisboa: FMH-UTL. 1997. Pp. 71-89.

27. RODRIGUES J. O Desconto de Tempo e a Marcha do Marcador de Basquetebol. Trabajo fin de carrera. Oporto: Faculdade de Ciencias do Desporto e Educaçâo Física. 2000.

28. SAMPAIO J. Análise de jogo em Basquetebol: Estudos e perspectivas. In: Tavares $F$, Janeira M, Graça A, Pinto D, Brandão E. (Eds.). Tendências Actuais da Investigação em Basquetebol. Porto: FCDEF-UP. 2001. Pp. 16-30. 
29. SAMPAIO J, LORENZO A, RIBERO C. Momentos críticos en los partidos de baloncesto: metodología para identificación y análisis de los acontecimientos precedentes. Cultura,Ciencia y Deporte. 2006; 5(2):83-88.

30. SÁNCHEZ M, SÁENZ-LÓPEZ P, JIMÉNEZ FJ, SIERRA A, IBÁÑEZ SJ, PÉREZ DE RUEDA R. EI desarrollo de la pericia en baloncesto: claves para la formación del jugador de alto rendimiento. Apunts, Educación fisica y deportes. 2006; 83:52-60.

31. TABACHNICK B, FIDELL L. Using Multivariate Statistics: 5 ed. Boston: Pearson. 2007.

32. THINNES RI. The debate over rally scoring. Coaching Volleyball. 1992.

33. VALLE A, ANTÚNEZ A, SÁEZ FJ, GARCÍA A, CAÑADAS M. Pilot study of use, distribution and efficacy of time-outs in Asobal Handball League. E-balonmano.com: Revista de Ciencias del Deporte. 2012; 8(3):191-199.

34. ZHANG R. Preparación para la competición de equipos de alto nivel y el papel del entrenador durante el partido. International Volley Tech. 1993; 4(93):2-5.

35. ZETOU E, HARITONIDIS C. Teaching Volleyball. Volume II. Thessaloniki: University Studio Press. 2002.

36. ZETOU E, KOURTESIS T, GIAZITZI K, MICHALOPOULOU M. Management and content analysis of timeout during volleyball games. International Journal of Performance Analysis in Sport. 2008; 8(1):44-55. 